University of Nebraska - Lincoln

DigitalCommons@University of Nebraska - Lincoln

\title{
Victim, perpetrator, family, and incident characteristics of infant and child homicide in the United States Air Force
}

Don R. Lucas

Northwest Vista College

Kelley C. Wezner

Northern Illinois University

Joel S. Milner

Northern Illinois University

Thomas R. McCanne

Northern Illinois University

I. Nell Harris

Brooks Air Force Base

See next page for additional authors

Follow this and additional works at: https://digitalcommons.unl.edu/usafresearch

Part of the Aerospace Engineering Commons

Lucas, Don R.; Wezner, Kelley C.; Milner, Joel S.; McCanne, Thomas R.; Harris, I. Nell; Monroe-Posey, Carla; and Nelson, John P., "Victim, perpetrator, family, and incident characteristics of infant and child homicide in the United States Air Force" (2002). U.S. Air Force Research. 24.

https://digitalcommons.unl.edu/usafresearch/24

This Article is brought to you for free and open access by the U.S. Department of Defense at DigitalCommons@University of Nebraska - Lincoln. It has been accepted for inclusion in U.S. Air Force Research by an authorized administrator of DigitalCommons@University of Nebraska - Lincoln. 


\section{Authors}

Don R. Lucas, Kelley C. Wezner, Joel S. Milner, Thomas R. McCanne, I. Nell Harris, Carla Monroe-Posey, and John P. Nelson 


\title{
Victim, perpetrator, family, and incident characteristics of infant and child homicide in the United States Air Force
}

\author{
Don R. Lucas ${ }^{\mathrm{a}}$, Kelley C. Wezner ${ }^{\mathrm{b}}$, Joel S. Milner ${ }^{\mathrm{b}}$, \\ Thomas R. McCanne ${ }^{\mathrm{b}, *}$, I. Nell Harris ${ }^{\mathrm{c}}$, Carla Monroe-Posey ${ }^{\mathrm{c}}$, \\ John P. Nelson ${ }^{\mathrm{c}}$ \\ ${ }^{a}$ Psychology Department, Northwest Vista College, San Antonio, TX, USA \\ ${ }^{\mathrm{b}}$ Center for the Study of Family Violence and Sexual Assault, Northern Illinois University, DeKalb, IL, USA \\ ${ }^{\mathrm{c}}$ Headquarters Family Advocacy Program, Brooks Air Force Base, San Antonio, TX, USA
}

Received 24 June 1999; received in revised form 27 July 2001; accepted 3 August 2001

\begin{abstract}
Objective: The present study describes factors related to fatal abuse in three age groups in the United States Air Force (USAF).

Method: Records from 32 substantiated cases of fatal child abuse in the USAF were independently reviewed for 60 predefined factors.

Results: Males were over-represented in young child victims (between 1 year and 4 years of age) and child victims (between 4 years and 15 years of age) but not in infant victims (between 24 hours and 1 year of age). African-American infant victims and perpetrators were over-represented. Younger victims were more likely to have been previously physically abused by the perpetrator. Perpetrators were predominantly male and the biological fathers of the victims. Infant and young child perpetrators reported childhood abuse histories, while child perpetrators reported the highest frequency of mental health contact. Victims' families reported significant life stressors. Families of young child victims were more likely divorced, separated, or single. Incidents with infants and young children tended to occur without witnesses; incidents with child victims tended to have the victim's sibling(s) and/or mother present. Fatal incidents were more frequent on the weekend, in the home, and initiated by some family disturbance.

Conclusions: Differences among groups in factors related to infant and child homicide across age groups may assist in the development of more tailored abuse prevention efforts and may also guide future investigations. (c) 2002 Elsevier Science Ltd. All rights reserved.
\end{abstract}

Keywords: Filicide; Infanticide; Fatal abuse; Child physical abuse; Battered-child syndrome

\footnotetext{
* Corresponding author address: Department of Psychology, Northern Illinois University, DeKalb, IL 60115, USA.
}

0145-2134/02/\$ - see front matter (C) 2002 Elsevier Science Ltd. All rights reserved.

PII: S0145-2134(01)00315-5

This article is a U.S. government work, and is not subject to copyright in the United States. 


\section{Introduction}

There is a growing amount of research on family violence in the United States military (e.g., Brewster, Nelson, Hymel, Colby, Lucas, McCanne, \& Milner, 1998; Merrill, Hervig, \& Milner, 1996; Mollerstrom, Patchner, \& Milner, 1995; Raiha \& Soma, 1997; Rosen \& Martin, 1996; Wardinsky, Vizcarrondo, \& Cruz, 1995). However, only one of these studies has examined fatal abuse (Brewster et al., 1998). Brewster et al. described a number of factors associated with fatal abuse in the United States Air Force (USAF) in victims less than 1 year of age. In an effort to identify factors that might be used to prevent fatal abuse, the present study extended Brewster et al.'s sample to victims older than 1 year of age at the time of death.

\section{Different types of fatal abuse?}

Three general terms based on the age of the victims have been used in the family violence research literature to describe fatal abuse: neonaticide (e.g., Arboleda-Florez, 1976; Bonnet, 1993; D’Orban, 1979; Resnick, 1970), infanticide (e.g., Arboleda-Florez, 1975; Dumme, 1978; Hontela \& Reddon, 1996), and filicide (e.g., Holden, Burland, \& Lemmen, 1996; Husain \& Daniel, 1984; Resnick, 1969). Typically, the neonaticide victim ranges in age from birth to 24 hours, the infanticide victim ranges in age from birth to 1 year, and the filicide victim ranges in age from birth to 18 years (Pitt \& Bale, 1995).

Although the terms neonaticide, infanticide, and filicide are not independent of one another (e.g., a filicide victim may also be a neonaticide victim), their use in the research literature often creates the illusion that each term represents an exclusive phenomenon (Trocme \& Lindsey, 1996). In reference to the present sample, the term "filicide" was operationally defined as a killing of a child between 1 year and 15 years of age by a parent, guardian, and/or caretaker. All of the present filicide cases were substantiated (see Methods section) by the USAF Family Advocacy Program (FAP). The term "fatal abuse" is not an age-specific term and is used throughout the remaining text to refer to neonaticide, infanticide, and/or filicide (Jason, 1983).

\section{Study objectives}

The ambiguous nature of the fatal abuse terms in the research literature raises the question of whether or not different fatal abuse age groups actually do differ relative to circumstances other than the age of the victim (e.g., perpetrator, family, and incident factors; Bourget \& Bradford, 1990; Jason, Gilliand, \& Tyler, 1983; Pitt \& Bale, 1995; Trocme \& Lindsey, 1996). Thus, the present study's objectives were to determine what circumstances are similar and different among different fatal abuse age groups in the USAF. In this study we extended Brewster et al.'s research by adding two older age groups, and then compared across all three age groups to determine similarities and differences in fatal abuse incidents. 
Table 1

Forty-five factors examined to determine their association with the 32 USAF filicide cases

$\underline{\text { Victim }}$

General demographics. Gender, race, birth order.

Medical descriptors. Status of well-baby visits and immunizations, mother's perception of victim having colic, father's perception of victim having colic, physician's perception of victim having colic, history of physical trauma.

Death measures. Age, weight, length, manner of death, length of time between injury and death.

\section{Perpetrator}

General demographics. Gender, race, age, relationship to victim, first time parent?

Personal and professional history. Employment status, unfavorable job performance? Military status, military rank, alcohol abuse, abused in childhood?

Account of incident. Initial account true?

Family

General demographics. Familial status, number of adults, number of children, age of mother, age of father, mixed-race marriage?

History. Familial, financial, judicial, medical, or psychological life stressors?

$\underline{\text { Incident }}$

Witnesses. Number of children, number of adults.

Place. On/off military installation, in/out of home, USAF base.

Time. Time of day, day of week, month of year.

Potential catalyst. Involvement of alcohol, argument, crying, impending spousal break-up, and/or spousal affair.

Outcome. Perpetrator suicide?, length of prison sentences

\section{Methods}

USAF FAP, birth, medical, autopsy, and investigative records from 32 substantiated cases of filicide occurring in the USAF from September 1985 to June 1997 were independently reviewed by two reviewers for 60 predefined factors (see Tables 1 and 2).

\section{Cases}

Only death cases that fit the present operational definition of filicide were reviewed. Thus, the present sample of 32 victims was greater than 1 year and less than or equal to 15 years

\section{Table 2}

Fifteen factors used to determine which of the 32 USAF filicide cases had previous contact with professional agencies concerning violence

Victim

USAF FAP. Unsubstantiated and substantiated domestic/family violence cases, type of abuse/neglect. Perpetrator

USAF FAP. Unsubstantiated and substantiated domestic/family violence cases, type of abuse/neglect.

Law. History of contact with the law concerning violence.

Other. History of contact with prevention/intervention agency other than USAF FAP.

Family

USAF FAP. Unsubstantiated and substantiated domestic/family violence cases, type of abuse/neglect.

Other. History of contact with prevention/intervention agency other than USAF FAP. 
of age at the time of death. Further, the victim's death was caused by a parent, guardian, and/or caretaker. The USAF FAP substantiated the death as being a result of abuse.

\section{Materials}

Five information sources were reviewed for each case: (1) USAF FAP Child Abuse Incident Report, (2) birth record of victim, (3) medical record of victim, (4) autopsy record of victim, and (5) USAF Office of Special Investigation's (OSI) Record of the Investigation. From these five information sources, 60 factors were examined that fell into one of four categories: (1) Victim, (2) Perpetrator, (3) Family, or (4) Incident (see Tables 1 and 2).

\section{Procedure}

Initially, a Family Advocacy Treatment Manager assigned to a particular report of suspected filicide gathered data in the field. Family Advocacy Treatment Managers generally have training in clinical social work and psychology. Once the investigation stage of a suspected filicide incident was completed, a multidisciplinary Family Maltreatment Case Management Team was created to decide whether or not the case should be substantiated as a death resulting from abuse. The Family Maltreatment Case Management Team was comprised of the primary Family Advocacy Treatment Manager assigned to the case, OSI investigators, security force, the judge advocate, physicians/nurse practitioners, the chaplain, the family support director, and Child Protection Services (if available). Case substantiation was primarily based on information gained from: (1) physical exam/autopsy (e.g., bruises, scratches, burns, broken bones, etc.), (2) interviews of family members, friends, medical personnel, and other professionals involved in the report of abuse/death, and (3) family history (i.e., previous episode[s] of domestic/family violence). Lastly, two independent raters (co-authors) reviewed the five information sources for each case. Inter-rater agreement was calculated for every factor.

\section{Results}

Data for all factors were not obtained in each case because some of the cases' birth, medical, and/or autopsy records were incomplete or missing, or because the records of the investigations were unique (i.e., not all factors were investigated for each case). Thus, results for most factors are based on samples less than the total number of cases $(N=32)$. Sample sizes are noted in parentheses in Tables 3 through 6 . Most results are presented in percentages that have been rounded to the nearest whole percent. Because inter-rater agreement for all 60 factors was found to be greater than a predefined minimal agreement rate of $80 \%$, no factors were dropped from analysis because of low inter-rater agreements. The mean inter-rater agreement for the 60 factors was $98 \%$ with a range from $85 \%$ to $100 \%$.

The following section provides descriptive data for the 32 child cases unique to this study. A comparison of the current cases to the infant data provided by Brewster et al. (1998) then follows. 
Table 3

Infant, young child, and older child victim characteristics (cell sizes in parentheses)

\begin{tabular}{|c|c|c|c|c|}
\hline & $\begin{array}{l}\text { Infant deaths }{ }^{\mathrm{a}} \\
(n)\end{array}$ & $\begin{array}{l}\text { Young child deaths } \\
(n)\end{array}$ & $\begin{array}{l}\text { Older child deaths } \\
(n)\end{array}$ & $p$ values \\
\hline \multicolumn{5}{|l|}{ Demographics } \\
\hline Gender & & & & n.s. \\
\hline$\%$ Male & $52 \%(17)$ & $71 \%(17)$ & $62 \%(5)$ & \\
\hline$\%$ Female & $48 \%(15)$ & $29 \%(7)$ & $38 \%(3)$ & \\
\hline Race & & & & n.s. \\
\hline$\%$ White & $62 \%(18)$ & $74 \%(17)$ & $74 \%(6)$ & \\
\hline$\%$ African-American & $38 \%(11)$ & $26 \%(6)$ & $13 \%(1)$ & \\
\hline$\%$ Hispanic & $0 \%(0)$ & $0 \%(0)$ & $13 \%(1)$ & \\
\hline \multicolumn{5}{|l|}{ Medical descriptors } \\
\hline \multicolumn{5}{|l|}{ Physical trauma before death } \\
\hline$\%$ Yes & $55 \%(12)$ & $40 \%(6)$ & $17 \%(1)$ & \\
\hline$\%$ No & $45 \%(10)$ & $60 \%(9)$ & $83 \%(5)$ & \\
\hline Physician reported colic & & & & n.s. \\
\hline$\%$ Yes & $35 \%(7)$ & $11 \%(1)$ & $17 \%(1)$ & \\
\hline$\%$ No & $65 \%(13)$ & $89 \%(8)$ & $83 \%(5)$ & \\
\hline \multicolumn{4}{|l|}{ Mother reported colic } & n.s. \\
\hline$\%$ Yes & $10 \%(2)$ & $10 \%(1)$ & $0 \%(0)$ & \\
\hline$\%$ No & $90 \%(18)$ & $90 \%(9)$ & $100 \%(3)$ & \\
\hline \multicolumn{4}{|l|}{ Perpetrator reported colic } & n.s. \\
\hline$\%$ Yes & $13 \%(3)$ & $29 \%(2)$ & $0 \%(0)$ & \\
\hline$\%$ No & $87 \%(21)$ & $71 \%(5)$ & $100 \%(4)$ & \\
\hline \multicolumn{4}{|c|}{ Previous unsubstantiated abuse/neglect } & n.s. \\
\hline$\%$ Yes & $17 \%(5)$ & $24 \%(5)$ & $13 \%(1)$ & \\
\hline$\%$ No & $83 \%(24)$ & $76 \%(16)$ & $87 \%(7)$ & \\
\hline \multicolumn{4}{|c|}{ Previous substantiated abuse/neglect } & $<.05$ \\
\hline$\%$ Yes & $3 \%(1)$ & $23 \%(5)$ & $0 \%(0)$ & \\
\hline$\%$ No & $97 \%(28)$ & $77 \%(17)$ & $100 \%(9)$ & \\
\hline \multicolumn{5}{|l|}{ Death measures } \\
\hline \multicolumn{4}{|c|}{ Violent death without a weapon } & n.s. \\
\hline$\%$ Yes & $55 \%(17)$ & $48 \%(10)$ & $50 \%(2)$ & \\
\hline$\%$ No & $45 \%(14)$ & $52 \%(11)$ & $50 \%(2)$ & \\
\hline \multicolumn{4}{|l|}{ Death by gun shot or stabbing } & $<.01$ \\
\hline$\%$ Yes & $3 \%(1)$ & $33 \%(7)$ & $50 \%(2)$ & \\
\hline$\%$ No & $97 \%(30)$ & $67 \%(14)$ & $50 \%(2)$ & \\
\hline
\end{tabular}

${ }^{\mathrm{a}}$ Infant death data from Brewster et al. (1998).

\section{Victims}

The victims' mean age at death was 3.90 years $(S D=3.48)$. The mode and median birth order of the victim was one. Ninety-two percent of the victims were up-to-date on their USAF well-baby visits, and $80 \%$ of the victims had USAF standard's age-appropriate immunizations. These well-baby visits and immunization rates are consistent with national rates (Mustin, Holt, \& Connell, 1994).

The mean death weight of these children was 18.84 kilograms $(S D=17.52)$, with a mean length of $101.45 \mathrm{~cm}(S D=25.71)$, placing them at the 75th and 50th percentiles of normal weight and length for age, respectively. The majority of victim deaths were caused by head trauma (48\%); however, a substantial number of deaths were caused by gunshot (20\%). 
Abdominal injuries (12\%), drowning (8\%), stabbing (8\%), and asphyxiation (4\%) caused the remaining deaths. The modal and median date of death was the same day on which the injuries occurred, with $61 \%$ of the victims dying on the same day of the injuries. The mean day of death was 1.64 days after the fatal incident occurred $(S D=4.36)$.

\section{Perpetrators}

The majority of the perpetrators were employed on active military-duty at the time of the incident $(62 \%)$ as lower- and middle-level enlisted personnel. Twenty-two percent were civilian and 19\% were dependents. Additionally, 24\% had unfavorable job performance reports. In addition to USAF FAP reports of violence, $39 \%$ of perpetrators had a report of domestic/family violence (57\% child physical abuse, $29 \%$ child neglect, and $14 \%$ spouse emotional abuse) from another professional agency, and $12 \%$ had prior contacts with the law concerning violence. Previous alcohol abuse was reported by $32 \%$ of perpetrators. Only $16 \%$ of the perpetrators' initial accounts of the fatally abusive incident were consistent with the charges that were brought against them. (See Margolin, [1990] for an extensive examination of fatal-abuse perpetrators' false accounts.) Of the incidents in which the perpetrator did not take his or her own life and for which court records were available, $91 \%$ ended with the perpetrator being sentenced to prison. The mean sentence term was 23.36 years $(S D=$ 16.19), with a range of 5 years to 50 years. In addition, one perpetrator was sentenced to life and two others were sentenced to death.

\section{Family factors}

Families included in the present study were primarily composed of two adults and two children living in the home at the time of the incident. Mixed-race marriages comprised 14\% of the sample. Seven percent of the families had prior unsubstantiated USAF FAP (100\% child neglect) cases involving a family member other than the victim or perpetrator. Twenty-six percent of victims' families had prior substantiated USAF FAP $(71 \%$ child physical abuse, $14 \%$ child neglect, and $14 \%$ spouse emotional abuse) cases involving a family member other than the victim or perpetrator. Nineteen percent of victims' families had a prior report of domestic/family violence involving a family member other than the victim or perpetrator ( $80 \%$ child neglect and $20 \%$ spousal abuse) from some professional agency (e.g., Child Protection Services) other than the USAF FAP. Additionally, 8\% of the families had a prior infant/child die because of abuse.

\section{Incident factors}

The majority of the incidents $(94 \%)$ occurred in the perpetrator's home. Twenty-three different USAF bases were represented in the substantiated filicides; however, $81 \%$ of the incidents did not occur on military installations. The majority $(81 \%)$ of the incidents took place in the United States. The months of January (16\%), March (16\%), May (13\%), June (13\%), and July (13\%) accounted for $71 \%$ of the incidents. 


\section{Factors associated with filicide across three age groups}

The following section provides a comparison of Brewster et al.'s (1998) sample of victims (infants who were greater than 24 hours and less than 1 year of age) and the present study's sample of filicide victims divided into young child (greater than 1 year and less than or equal to 4 years of age) and child (greater than 4 years and less than or equal to 15 years) victims. All of the present study's factors will not be used in the comparison to conserve space. Instead, the factors composing Brewster et al.'s model of prevention (p. 99) will guide the comparison. Relevant percentages and cell sizes for the variables discussed are provided in Tables 3 through 6. Probability values for comparisons across age groups were obtained by calculating $\chi^{2}$ statistics or one way analyses of variance with follow-up Newman-Keuls analyses. The probability values should be interpreted with caution because of relatively small sample sizes in most cases.

\section{Victims}

General demographics. The gender of victims was almost equally distributed between male $(52 \%)$ and female (48\%) for infants (see Table 2). However, the gender of victims was much more likely male $(71 \%$ and $62 \%)$ than female $(29 \%$ and $38 \%)$ for young child and child victims, respectively (see Table 3 ). The race of infant victims was $62 \%$ White and $38 \%$ African American. The race of victims was more likely White (74\% and 74\%) as compared to African Americans (26\% and 13\%) and Hispanics (0\% and 13\%) for the young child and child victims, respectively (see Table 3 ).

Medical descriptors. The present study examined several factors to gauge how healthy the victims were before their death. To gauge possible prior abuse that resulted in injury, two measures of prior physical trauma were taken: (1) any physical injury that was noted by a physician before the fatal incident, or (2) any physical injury not related to the death injury noted by the coroner during autopsy after the fatal incident. Examples of these injuries included: cuts, scrapes, bruises, burns, broken bones, and fractured bones. Combining the findings in the medical and autopsy records, a report of physical trauma before death existed in $55 \%$ of the infant victim cases, $40 \%$ of the young child victim cases, and $17 \%$ of the child victim cases (see Table 3 ). To gauge the victims' temperament during his or her infancy, several measures of colic were taken. Colic has no adequate explanation yet, affects approximately $16 \%$ of all infants, and is most likely to occur in infants between birth and 6 months of age (Hide \& Guyer, 1982). The present study operationally defined colic as any report in the FAP, medical, and/or OSI records of whiney, fussy, crying, and/or colicky behavior exhibited by the victim. The colicky behavior must have had no obvious reason for occurring, and the behavior had to be chronic; that is, the records had to have shown it occurring for a minimum of one week. For example, a baby crying because it stubbed its toe would not have been labeled colic; however, a report of a baby incessantly crying for a week for no apparent reason would have been labeled colic. For the infant victims, more infants were perceived as being colicky by physicians compared to mothers and perpetrators (see Table 3). For young child and child victims during their infancy, the respective colic reports 
were $11 \%$ and $17 \%$ by physicians, $10 \%$ and $0 \%$ by mothers, and $29 \%$ and $0 \%$ by fathers (see Table 3).

Seventeen percent of the infant victims, $24 \%$ of the young child victims, and $13 \%$ of the child victims were involved in previous unsubstantiated cases of abuse and/or neglect with the USAF FAP (see Table 3). Three percent of the infant victims, 23\% of the young child victims, and none of the child victims were involved in previous substantiated cases of abuse and/or neglect with the USAF FAP (see Table 3). There was a significant difference among groups in involvement in substantiated abuse, with a disproportionate number of young child victims involved in previous substantiated FAP cases of child maltreatment $\left[\chi^{2}(2, N=\right.$ $60)=6.34, p<.05]$.

Death measures. Infants (55\%), young children (48\%), and children (50\%) were most likely killed without a weapon in a highly violent manner (e.g., head trauma; see Table 3). As victims grew older, they were more likely to be killed with a weapon, such as a gun or a knife $\left[\chi^{2}(2, N=56)=10.81, p<.01\right.$; see Table 3]. Gunshot or stabbing accounted for $3 \%$ of the infant deaths, $33 \%$ of the young child deaths, and $50 \%$ of the child deaths.

\section{Perpetrator}

General demographics. For all the fatal-abuse age groups, the gender of perpetrators was more likely to be male than female (see Table 4). The infant group perpetrators were $84 \%$ male, the young child group perpetrators were $75 \%$ male, and the child group perpetrators were $75 \%$ male. The breakdown of the perpetrators' races basically followed that found for the victim: the race of perpetrators was $64 \%$ White and 36\% African American for the infant group (see Table 4). The race of perpetrators was more likely White $(71 \%$ and $75 \%$ ) as compared to African Americans (29\% and 12\%) and Hispanics (0\% and 13\%) for the young child and child groups, respectively (see Table 4). Although the perpetrator was much more likely to be the father in each of the age groups, the young child group had a substantial minority of stepfathers $(25 \%)$, whereas the infant and child groups' had very few or no stepfathers $(3 \%$ and $0 \%)$, respectively $\left[\chi^{2}(4, N=54)=10.80, p<.05\right.$; see Table 4]. Also, it should be noted that the mother's boyfriend accounted for a substantial minority of the perpetrators in the young child (13\%) and child (14\%) groups.

Personal history. The infant (54\%) and young child (41\%) groups' perpetrators were more likely first-time parents of the victim, whereas the child (14\%) group's perpetrators were not (see Table 3). The infant group's perpetrators were more likely to have had a history of abuse in childhood, compared to young child and child groups' perpetrators (see Table 4). Lastly, mental health contacts were more frequently reported in perpetrators of young child and child deaths, when compared to perpetrators of infant deaths (see Table 4). Twenty-nine percent of the infant group perpetrators, $60 \%$ of the young child group perpetrators, and none of the child group perpetrators were in contact (unsubstantiated and/or substantiated cases of abuse and/or neglect) with the USAF FAP (see Table 4). Whether or not perpetrators had been in contact with the USAF FAP was found to be significantly different among groups $\left[\chi^{2}(2, N=\right.$ $55)=9.59, p<.01]$. 
Table 4

Infant, young child, and older child perpetrator characteristics (cell sizes in parentheses)

\begin{tabular}{|c|c|c|c|c|}
\hline & $\begin{array}{l}\text { Infant deaths } \\
\text { (from Brewster } \\
\text { et al., 1998) } \\
(n)\end{array}$ & $\begin{array}{l}\text { Young child } \\
\text { deaths }(n)\end{array}$ & $\begin{array}{l}\text { Older child } \\
\text { deaths }(n)\end{array}$ & $p$ values \\
\hline \multicolumn{5}{|l|}{ Demographics } \\
\hline Gender & & & & n.s. \\
\hline$\%$ Male & $84 \%(26)$ & $75 \%(18)$ & $75 \%(6)$ & \\
\hline$\%$ Female & $16 \%(5)$ & $25 \%(6)$ & $25 \%(2)$ & \\
\hline Race & & & & n.s. \\
\hline$\%$ White & $64 \%(20)$ & $71 \%(17)$ & $75 \%(6)$ & \\
\hline$\%$ African- & $36 \%(11)$ & $29 \%(7)$ & $12 \%(1)$ & \\
\hline \multicolumn{5}{|l|}{ America } \\
\hline \% Hispanic & $0 \%(0)$ & $0 \%(0)$ & $13 \%(1)$ & \\
\hline$\underline{\text { Role }}$ & & & & $<.05$ \\
\hline$\%$ Father & $80 \%(24)$ & $58 \%(14)$ & $71 \%(5)$ & \\
\hline$\%$ Stepfather & $3 \%(1)$ & $25 \%(6)$ & $0 \%(0)$ & \\
\hline \% Boyfriend & $0 \%(0)$ & $13 \%(3)$ & $14 \%(1)$ & \\
\hline \multicolumn{5}{|l|}{ Personal characteristics } \\
\hline First-time parents & & & & n.s. \\
\hline$\%$ Yes & $54 \%(15)$ & $41 \%(7)$ & $14 \%(1)$ & \\
\hline$\%$ No & $46 \%(13)$ & $59 \%(10)$ & $86 \%(6)$ & \\
\hline History of abuse & & & & n.s. \\
\hline$\%$ Yes & $23 \%(6)$ & $12 \%(2)$ & $0 \%(0)$ & \\
\hline$\%$ No & $77 \%(20)$ & $88 \%(15)$ & $100 \%(7)$ & \\
\hline Mental health & & & & n.s. \\
\hline \multicolumn{5}{|l|}{ contact } \\
\hline$\%$ Yes & $21 \%(5)$ & $33 \%(7)$ & $43 \%(3)$ & \\
\hline$\%$ No & $79 \%(19)$ & $67 \%(14)$ & $57 \%(4)$ & \\
\hline USAF FAP contact $^{\mathrm{a}}$ & & & & $<.01$ \\
\hline$\%$ Yes & $29 \%(8)$ & $60 \%(12)$ & $0 \%(0)$ & \\
\hline$\%$ No & $71 \%(20)$ & $40 \%(8)$ & $100 \%(7)$ & \\
\hline
\end{tabular}

${ }^{a}$ Contact with the USAF FAP indicated unsubstantiated and/or substantiated cases of abuse and/or neglect involving the perpetrator.

\section{Family}

General demographics. Families' parental status differed among fatal-abuse age groups $\left[\chi^{2}\right.$ $(2, N=63)=8.70, p<.05$; see Table 5]. Most families were comprised of two married adults. The infant (6\%) and child (14\%) victim groups had a few families composed of single-parent households, whereas the young child group had a substantial minority of families that were single-parent (25\%), and to a lesser extent, separated-parent (8\%) and divorced-parent (4\%) households (see Table 5). As expected, the parents' ages increased across fatal-abuse age groups $(p<.01$ for both analyses; see Table 5). The mothers' and fathers' respective mean ages in the infant victim group were 23.26 years and 24.30 years; in the young child victim group, they were 26.33 years and 28.72 years; in the child victim group, they were 36.14 years and 33.71 years. 
Table 5

Infant, young child, and older child family characteristics (cell sizes in parentheses)

\begin{tabular}{|c|c|c|c|c|}
\hline & $\begin{array}{l}\text { Infant deaths } \\
\text { (from Brewster } \\
\text { et al., 1998) } \\
(n)\end{array}$ & $\begin{array}{l}\text { Young } \\
\text { child } \\
\text { deaths }(n)\end{array}$ & $\begin{array}{l}\text { Older } \\
\text { child } \\
\text { deaths } \\
(n)\end{array}$ & $p$ values \\
\hline \multicolumn{5}{|l|}{ Demographics } \\
\hline Parental marital status & & & & $<.05$ \\
\hline$\%$ Married & $94 \%(29)$ & $63 \%(15)$ & $86 \%(7)$ & \\
\hline$\%$ Unmarried & $6 \%(2)$ & $37 \%(9)$ & $14 \%(1)$ & \\
\hline Maternal Age (M) & $23.26(23)$ & $26.33(18)$ & $36.14(7)$ & $\leq .01$ \\
\hline Paternal Age (M) & $24.30(30)$ & $28.72(18)$ & $33.71(7)$ & $<.01$ \\
\hline \multicolumn{5}{|l|}{ Family history } \\
\hline Life stressors within month & & & & $<.01$ \\
\hline$\%$ Yes & $26 \%(7)$ & $59 \%(10)$ & $86 \%(6)$ & \\
\hline$\%$ No & $74 \%(20)$ & $41 \%(7)$ & $14 \%(1)$ & \\
\hline$\underline{\text { USAF FAP case }}^{\mathrm{a}}$ & & & & n.s. \\
\hline$\%$ Yes & $19 \%(5)$ & $32 \%(6)$ & $13 \%(1)$ & \\
\hline$\%$ No & $81 \%(22)$ & $68 \%(13)$ & $87 \%(7)$ & \\
\hline
\end{tabular}

${ }^{a}$ Prior USAF FAP substantiated case(s) of abuse and/or neglect involving a family member other than the victim or the perpetrator.

History. Previous research has reported a number of significant stressors that most people experience at some point during their life (Holmes \& Masuda, 1974; Schroeder \& Costa, 1984). Some of these life stressors include family divorce, death of a family member or close friend, moving into a new home, and major illness. Life stressors may have negative psychological and physical effects on individuals or families (Depue \& Monroe, 1986; Fiala \& LaFree, 1988; Trocme \& Lindsey, 1996). Life stressors present in filicide victims' families during the month preceding the fatal incident were identified. The number of families that had life stressors within one month of the fatal incident increased with the age of the victim $\left[\chi^{2}(2, N=51)=9.94, p<.01\right.$; see Table 5]. Twenty-six percent of the infant group families had at least one life stressor, $59 \%$ of the young child group families had at least one life stressor, and $86 \%$ of the child group families had at least one life stressor. Nineteen percent of the infant group families, $32 \%$ of the young child group families, and $13 \%$ of the child group families had prior substantiated USAF FAP abuse and/or neglect cases involving a family member other than the victim or perpetrator (see Table 5).

\section{Incident}

Witnesses. Infant and young child filicide incidents had no other children or adults, besides the victim and the perpetrator, present during the fatal incident (see Table 6). However, the child group incidents had one person less than 18 years of age and/or one adult present to witness the fatal incident (see Table 6).

Time. Infant group incidents occurred around noon $(M=12: 17$ p.m., $M d n=11: 23$ a.m., mode $=11: 00$ a.m. $)$; young child group incidents occurred during the afternoon $(M=2: 12$ 
Table 6

Infant, young child, and older child Incident characteristics (cell sizes in parentheses)

\begin{tabular}{|c|c|c|c|c|}
\hline & $\begin{array}{l}\text { Infant deaths } \\
\text { (from Brewster } \\
\text { et al., 1998) } \\
(n)\end{array}$ & $\begin{array}{l}\text { Young child } \\
\text { deaths }(n)\end{array}$ & $\begin{array}{l}\text { Older child } \\
\text { deaths }(n)\end{array}$ & $p$ values \\
\hline \multicolumn{5}{|l|}{ Witnesses } \\
\hline \multicolumn{5}{|l|}{ Child witnesses } \\
\hline Median & $0(29)$ & $0(21)$ & $1(8)$ & \\
\hline Mode & $0(29)$ & $0(22)$ & $1(8)$ & \\
\hline \multicolumn{5}{|l|}{ Adult witnesses } \\
\hline Median & $0(29)$ & $0(21)$ & $1(8)$ & \\
\hline Mode & $0(29)$ & $0(22)$ & $1(8)$ & \\
\hline \multicolumn{5}{|l|}{ Time } \\
\hline \multicolumn{5}{|l|}{ Time of day } \\
\hline Mean & 12:17 PM (25) & 2:12 PM (20) & 9:00 AM (7) & $<.01$ \\
\hline Median & 11:23 AM & 2:48 PM & 6:00 AM & \\
\hline Mode & 11:00 AM & 5:00 PM & 6:00 AM & \\
\hline Day of Week & & & & n.s. \\
\hline$\%$ Weekend Day & $47 \%(13)$ & $52 \%(11)$ & $50 \%(4)$ & \\
\hline \% Weekday & $53 \%(15)$ & $48 \%(10)$ & $50 \%(4)$ & \\
\hline \multicolumn{5}{|l|}{ Potential catalyst } \\
\hline Incident catalyst & & & & n.s. \\
\hline$\%$ Yes & $58 \%(14)$ & $59 \%(10)$ & $87 \%(7)$ & \\
\hline$\%$ No & $42 \%(10)$ & $41 \%(7)$ & $13 \%(1)$ & \\
\hline \multicolumn{5}{|l|}{ Outcome } \\
\hline Murder-suicides $^{\mathrm{a}}$ & & & & $<.05$ \\
\hline$\%$ Yes & & $13 \%(3)$ & $50 \%(4)$ & \\
\hline$\%$ No & & $87 \%(20)$ & $50 \%(4)$ & \\
\hline
\end{tabular}

${ }^{a}$ Data on the murder-suicides of the perpetrator-victim dyad not available for the infant victims from the Brewster et al. 1998 report.

p.m., $M d n=2: 48$ p.m., mode $=5: 00$ p.m.); and child group incidents occurred during the morning ( $M=$ 9:00 a.m., $M d n=6: 00$ a.m., mode $=6: 00$ a.m.; see Table 6). The weekends were the most probable time for the fatal incident to occur: $47 \%$ of the cases in the infant group occurred on Saturday or Sunday, $52 \%$ of the cases in the young child group occurred on Saturday or Sunday, and $50 \%$ of the cases in the child group occurred on Saturday or Sunday. Of interest, only 1 of the 57 cases in all the groups occurred on a Monday.

Potential catalyst. The catalyst was defined as any obvious, disturbing situation that occurred immediately before the fatal incident. It should be noted that catalysts could be similar to or the same as life stressors measured in family history. Sixty-eight percent of the incidents involved a catalyst. Of these incidents, the primary catalyst was either an argument (6\%), crying $(35 \%)$, or an impending spousal break-up (59\%). The perpetrator was documented to be consuming alcohol in $16 \%$ of the incidents. The number of incidents with potential catalysts increased as the fatal-abuse age groups increased (see Table 6). Fifty-eight percent of infant group incidents had some incident catalyst, $59 \%$ of young child group incidents had some incident catalyst, and $87 \%$ of child group incidents had some incident catalyst. 
Outcome. The probability the incident ended in murder-suicide of the victim-perpetrator increased as the fatal-abuse age group increased $\left[\chi^{2}(1, N=31)=4.64, p<.05\right.$; see Table 6 ]. Data were not available for murder-suicides in the infant group incidents; however, $13 \%$ of the incidents in the young child group ended in murder-suicide, and $50 \%$ of the incidents in the child group ended in murder-suicide.

\section{Discussion}

\section{Victims}

General demographics. While infant victims were equally likely to be male or female (Brewster et al., 1998), young child and child filicide victims were more likely to be male. This gender difference is consistent with Finkelhor and Dziuba-Letherman's (1994) conjecture that males have an increasing risk to be victims of fatal abuse with increasing age. Although some reports (e.g., US Department of Health and Human Services, 1997) and studies (e.g., Anderson, Ambrosino, Valentine, \& Lauderdale, 1983; Jason et al., 1983; Goetting, 1988; Margolin, 1990; Schmidt, Grab, \& Madea, 1996) have shown the majority of fatal abuse victims to be male, the gender of fatal abuse victims generally varies in the research literature as being either predominately female or equally male and female (e.g., Brewster et al., 1998; Hicks \& Gaughan, 1995; Jason \& Andereck, 1983; Schloesser, Pierpont, \& Poertner, 1992). The findings of the present study suggest that one possible reason for the victim gender differences in published reports and studies may be because of varying definitions of filicide. The racial composition of the young child and child filicide victims in the present study were consistent with the active duty USAF population (Airman, 1997), although White infant victims were under-represented and African American infant victims were over-represented (Brewster et al., 1998). The present finding is consistent with national rates showing that the risk for homicide of African American infants is more than three times that of White infants (US Department of Health and Human Services, 1992). Additionally, others have reported African Americans to be over-represented among child maltreatment (e.g., Plass, 1993) and fatal abuse (e.g., Anderson et al., 1983; Christoffel, Anzinger, \& Merrill, 1989; Goetting, 1988; Jason \& Andereck, 1983) victims. However, discrepancies in racial composition of fatal abuse victims may be confounded by factors related to social economic status (Bourget \& Bradford, 1990; Fiala \& LaFree, 1988; Goetting, 1988; Jason \& Andereck, 1983). Because the perpetrators' race did not markedly differ from the victims' race, the preceding discussion may also be applied to the perpetrator's race.

Filicide victims were usually the first born. These results are consistent with many previous studies that have reported victims of fatal abuse to be the first born or only child (Anderson et al., 1983; Jacquot \& Roberts, 1988; Mitchell, 1989; Myers, 1970; Thompson \& Wilson, 1989).

Medical descriptors. About 25\% of the present study's victims had physical injuries that required medical attention at some time before the victims' death. Further, the younger the 
fatal-abuse victim was, the more likely previous physical injuries had occurred. This finding may have implications for prevention and/or intervention related to fatal abuse. Although there were relatively small sample sizes for the data pertaining to colic, the colic data suggest differential personality characteristics in the perpetrators across groups. Hide and Guyer (1982) examined a large sample $(N=843)$ of infants and determined the population incidence of colic was about $16 \%$. Relative to this population estimate, only $8 \%$ of mothers and $13 \%$ of physicians reported the present filicide victims to be colicky during their infancy, compared to $18 \%$ of fathers. Brewster et al. (1998) hypothesized that the relative underreporting of colic by mothers, compared to physicians, might be because of attempts to disguise previous abusive episodes. The physicians' over-reporting, compared to mothers, may have been because of the physicians "picking up" (although unbeknownst to them) on the previous abusive episodes. That is, the signs of colic (i.e., chronic whining, fussing, crying, etc.) that the physicians noticed resulted from (1) the pain suffered by the infants because of previous abuse, and/or (2) the pain suffered by the infants because of actually having colic. In contrast to relative lower frequencies of reporting colic, fathers of young child victims seemed to over-report colic during their child's infancy.

By combining the varying reports of colic by fathers across age groups with the findings of previous physical injuries in infant and young child victims, it may be argued that perpetrators of fatal infant and young child abuse have illusory perceptions about their infant's or child's behavior. Expanding upon Brewster et al.'s (1998) hypothesis, it may be that the fathers of infant victims abrogate colicky behavior from their infants to cover up previous abusive deeds, whereas the fathers of young child victims project colicky behavior upon their infants as an excuse for previous abusive deeds (e.g., Margolin, 1990). Consistent with this hypothesis are previous studies finding child maltreatment perpetrators to have negative perceptions of their child despite the child's disposition being veridically positive (e.g., Korbin, 1987).

Death measures. The most likely manner of death was head trauma for all filicide victims. However, the manner of death changed with age: as victims grew older, the means of death became more violent. This result is consistent with previous studies that have found the majority of infanticide cases to have been caused by head injuries (e.g., Hargrave \& Warner, 1992; Hicks \& Gaughan, 1995; Jacquot \& Roberts, 1988; Schloesser et al., 1992), and the majority of filicide cases to have been caused by gunshot or stabbing (Christoffel et al., 1989; Jason, 1983).

\section{Perpetrator}

General demographics. The father was found to be the most likely candidate for committing fatal abuse with any age victim. The likelihood of the perpetrator being a stepfather or other nonbiological male parental figure increased with increasing age. Prior studies are mixed on whether the father (e.g., Hicks \& Gaughan, 1995; Schloesser et al., 1992) or the mother (e.g., Barlow \& Clayton, 1996; Bonnet, 1993; Goetting, 1988; Jason, 1983; Jason et al., 1983; Korbin, 1987; Schloesser et al., 1992; Schmidt et al., 1996) is the most likely perpetrator of fatal abuse. However, previous studies show that fathers are the most likely perpetrators to 
be involved in more violent causes of death (e.g., gunshot, severe head trauma, stabbing, etc.), whereas mothers are the most likely to be involved in neonaticide and, generally, in less violent manners of death (e.g., asphyxiation, drowning, neglect, etc.).

Personal history. The personal histories of the present study's perpetrators were remarkable for two reasons. Rates of self-reports of physical and/or sexual childhood abuse by perpetrators decreased with increasing age of their victims. Kaufman and Zigler (1987), as well as others (e.g., Bell, 1973; Hunter \& Kilstrom, 1979), conclude that an abuse history is a strong indicator of future abuse. Relative to Kaufman and Zigler's calculated base rate for abuse of $5 \%$ in the general population, only the infant $(23 \%)$ and young child (12\%) group's perpetrators' self-reported rates appear to provide support for the intergenerational hypothesis (i.e., previous abuse leads to future abuse). The difference between the infant and young child group's perpetrators and the child group's perpetrators may be explained by the following result concerning perpetrator's mental-health history. Increasing age of the victim seems to be associated with an increasing likelihood of the perpetrator having some contact with mental health providers before the fatal incident. Several studies in the research literature have discussed the role psychopathology plays in fatal abuse (e.g., Bourget \& Bradford, 1990; Button \& Revich, 1972; Schmidt et al., 1996). Although a few of the past studies have examined the male perpetrator (father), most of these studies have focused on the female perpetrator (mother). These studies report depressed mothers to be more likely to be associated with neonaticide and infanticide, whereas character-disordered fathers are more likely to be associated with violent manners of fatal abuse. Although the present study's results cannot address the type of psychopathology associated with the perpetrators, the present results do show that perpetrators with concerns about mental health are more likely associated with older victims than younger victims.

\section{Family}

General demographics. Families were most likely composed of married households. Families of young child victims had the largest minority of single-parent, separated, and divorced households. Most previous descriptions on fatal child abuse families (e.g., Margolin, 1990) are like Kempe, Silverman, Steele, Droegemueller, and Silver's (1962) initial description of the battered-child-syndrome family: a broken, dysfunctional household composed of a single parent. The present findings show Kempe et al.'s description may hold true for young child fatal-abuse families, but not for infant or child fatal-abuse families.

History. The present study found that the majority of families of young child and child victims had some significant life stressor (Holmes \& Masuda, 1974; Schroeder \& Costa, 1984) within 1 month of the fatal incident. The presence of life stressors in this population is consistent with other studies that have reported that stressors related to the disruption of a family's structure (e.g., divorce) and economic hardship are associated with child abuse and homicide (e.g., Fiala \& LaFree, 1988). Further, the present results extend previous reports by showing that life stressors are more likely associated with fatal abuse of older children compared with fatal abuse of infants. 


\section{Incident}

Witnesses. On average, no other individuals other than the victim and perpetrator were present to witness the fatal incident upon the infant (Brewster et al., 1998) and young child. However, at least one adult and one child in addition to the victim and perpetrator were present to witness the fatal incident upon the child. Cohen and Felson (1979) have argued that homicide is most apt to occur in the absence of capable guardians. Goetting (1988) reported empirical support for this argument when she found $61 \%$ of her sample of filicide cases occurred with no witnesses. The present results suggest there is an age trend associated with the number of witnesses: the older the victim, the more witnesses there will be to the fatal incident.

Time. The weekend days were the most likely days for fatal abuse to occur in each of the age groups. Only two other studies besides Brewster et al.'s (1998) have previously examined the day of the fatal incident. Goetting (1988) found no systematic variation with the day of death, whereas Schmidt et al. (1996) reported $56 \%$ of their sample of filicide cases occurred on the weekend. The 5 months when filicide was most likely to occur coincided with winter (January), spring (March), and summer (May through July) vacations from school or preschool. This finding, combined with the preceding finding concerning the day of the week, suggests that fatal abuse is most likely to occur when the parent (perpetrator) and the infant/child (victim) spend the greatest amount of time together. Specifically, the weekends (and vacation months for [pre]school age children) are the most probable time for abuse to occur because the father (most probable perpetrator) may be home from work and the infant/child is home from (pre)school. On a related note, several criminal theorists (Bensing, Schroeder, \& Jackson, 1960; Voss \& Hepburn, 1968; Wolfgang, 1958) have argued there is a "leisure-related temporal order to homicide" (Goetting, 1988, p. 343).

Catalyst. The majority of filicide incidents involved a catalyst, and the most likely catalyst in all age groups was an argument between parents that was concerned with an impending marital breakup. Only one other study in the previous research literature besides Brewster et al. (1998) reported on incident catalysts. Jason (1983) reported an argument to be the most likely discernable precipitating event to a victim's homicide. However, the potential overlap between family history of life stressors and incident catalysts should be considered, particularly since both included marital dysfunction.

Outcome. The one remarkable finding concerning the outcome of the fatal-abuse incident was the number of murder-suicides among the young child and child groups. Several previous studies have commented on the relationship of murder-suicides to fatal abuse (Abramsky \& Helfman, 1996; Bourget \& Bradford, 1990; Somander \& Rammer, 1991; Resnick, 1969; Trocme \& Lindsey, 1996). Generally, these studies report significant portions (from $13 \%$ to $71 \%$ ) of fatal-abuse cases end in the suicide of the perpetrator. The present results suggest that the older the victim, the more likely the fatal-abuse incident will end in murder-suicide. One reason for this association may be the older the victim, the more 
difficult it is for the perpetrator to "cover up" the crime (e.g., it is difficult to argue sudden-infant-death syndrome for the cause of death of an 11-year-old).

\section{Contact with fatal-abuse victims, perpetrators, and families}

The family violence research literature, specifically the literature concerned with fatal abuse, is mixed in its view of whether (e.g., Anderson et al., 1983; Hargrave \& Warner, 1992; Hicks \& Gaughan, 1995; Krugman, 1995) or not (e.g., Zumwalt \& Hirsch, 1987) fatal-abuse victims, perpetrators, and/or families have contact with professional agencies concerning domestic/family violence/neglect before the fatal incident. These mixed findings may be because of the period of time during which a sample was obtained. Participants in older sample populations (pre-1980) relative to participants in more recent sample populations (post 1980) may have lower probabilities of being involved in previous domestic/family violence/neglect cases simply because the infrastructures for prevention/intervention programs for the older sample populations were less established. In other words, laypersons and professionals have a greater awareness of child abuse today than they may have 20 years ago (Gelles \& Straus, 1988). Since 1980, mandatory rules for reporting child abuse have been established (Finkelhor, 1993), the public's awareness about child abuse has increased (e.g., Duncan, 1996; Goddard \& Liddell, 1995; Hewitt, 1997), active surveillance of child abuse has been implemented (e.g., US Department of Health and Human Services, 1996, 1997), and scientific research on child abuse has increased (e.g., Brewster et al., 1998). The present findings, as well as Brewster et al.'s, are based upon recent samples of participants and show a substantial portion of these participants were involved in domestic/family violence/neglect cases before the fatal incident.

\section{Methodological problems}

At least two methodological problems need to be considered as potential limitations. First, the present study's overall sample is small. However, the present sample is relatively large in comparison to many of the previous studies on fatal abuse (e.g., Hicks \& Gaughan, 1995; Husain \& Daniel, 1984; Kasim, Cheah, \& Shafie, 1995; Schmidt et al., 1996). Further, since fatal abuse occurs in less than 1 out of every 2000 child-abuse cases (Trocme \& Lindsey, 1996), a completely adequate sample may not be practical. Furthermore, none of the previous studies on fatal abuse with larger sample sizes examined military populations, and few of these studies had as many factors as the present study (e.g., Christoffel, Anzinger, \& Merrill, 1989; Daly \& Wilson, 1994; Ewigman, Kivlahan, \& Land, 1993; Hargrave \& Warner, 1992; Schloesser et al., 1992; Starling, Holden, \& Jenny, 1995).

Secondly, the lack of comparison groups may also be a limitation. The present study made as many comparisons to baseline information reported in the research literature as possible. However, because of its exploratory nature, the present study did not incorporate complex inferential statistics nor did it include a comparison group. A fruitful extension of the present study would be to incorporate inferential statistics with a military, no child abuse comparison group. Additionally, a military, nonfatal child abuse group also may be a worthy comparison group (e.g., Husain \& Daniel, 1984). 
In summary, despite the limitations noted above, the present data suggest several factors that appear to differentiate between infant, young child, and older child filicide victims. Future research focused on the factors associated with death in these three age groups should be helpful in increasing our understanding of the etiology of filicide. In addition, increased awareness and understanding of the factors that differentiate these three types of filicide may help in developing programs designed to identify and/or prevent child homicide.

\section{References}

Abramsky, M. F., \& Helfman, M. (1996). Murder-suicide. In H. V. Hall (Ed.), Lethal violence 2000 (pp. 293-310). Kamuela, HI: Pacific Institute for the Study of Conflict and Aggression.

Airmen. (1997, January). Database. Vol. 41 (pp. 28-47).

Anderson, R., Ambrosino, R., Valentine, D., \& Lauderdale, M. (1983). Child deaths attributed to abuse and neglect: an empirical study. Child and Youth Services Review, 5, 75-89.

Arboleda-Florez, J. (1975). Infanticide: some medicolegal considerations. Canadian Journal of Psychiatry, 20, $55-60$.

Arboleda-Florez, J. (1976). Neonaticide. Canadian Journal of Psychiatry, 21, 31-34.

Barlow, S. H., \& Clayton, C. J. (1996). When mothers murder: understanding infanticide by females. In H. V. Hall (Ed.), Lethal violence 2000 (pp. 203-229). Kamuela, HI: Pacific Institute for the Study of Conflict and Aggression.

Bell, G. (1973). Parents who abuse their children. Canadian Psychiatric Association Journal, 18, 223-228.

Bensing, R. C., Schroeder, O., \& Jackson, P. B. (1960). Homicide in an urban community. Springfield, IL: Thomas.

Bonnet, C. (1993). Adoption at birth: prevention against abandonment or neonaticide. Child Abuse \& Neglect, 17, 501-513.

Bourget, D., \& Bradford, J. M. W. (1990). Homicidal parents. Canadian Journal of Psychiatry, 35, 233-238.

Brewster, A. L., Nelson, J. P., Hymel, K. P., Colby, D. R., Lucas, D. R., McCanne, T. R., \& Milner, J. S. (1998). Victim, perpetrator, family, and incident characteristics of 32 infant-maltreatment deaths in the United States Air Force. Child Abuse \& Neglect, 22, 91-101.

Button, J. H., \& Revich, R. S. (1972). Obsessions of infanticide. Archives of General Psychiatry, 27, 235-240.

Christoffel, K. K., Anzinger, N. K., \& Merrill, D. A. (1989). Age-related patterns of violent death, Cook County, Illinois, 1977 through 1982. American Journal of Diseases of Children, 143, 1403-1409.

Cohen, L. E., \& Felson, M. (1979). Social change and crime rate trends: a routine activity approach. American Sociological Review, 44, 588-608.

D'Orban, P. T. (1979). Women who kill their children. British Journal of Psychiatry, 134, 560-571.

Daly, M., \& Wilson, M. I. (1994). Some differential attributes of lethal assaults on small children by stepfathers versus genetic fathers. Ethnology and Sociobiology, 15, 207-217.

Depue, R. A., \& Monroe, S. M. (1986). Conceptualization and measurement of human disorder in life stress research: the problem of chronic disturbance. Psychological Bulletin, 99, 36-51.

Dumme, C. (1978). Infanticide: the worth of the infant under law. Medical History, 22, 1-24.

Duncan, D. E. (1996). One deadly week. Life, (September), 52-58.

Ewigman, B., Kivlahan, C., \& Land, G. (1993). The Missouri child fatality study: underreporting of maltreatment fatalities among children younger than 5 years of age, 1983 through 1986. Pediatrics, 91, 330-337.

Fiala, R., \& LaFree, G. (1988). Cross-national determinants of child homicide. American Sociological Review, 53, 432-445.

Finkelhor, D. (1993). Main problem is still underreporting, not overreporting. In R. J. Gelles \& D. R. Loeske (Eds.), Current controversies on family violence (pp. 273-287). Newbury Park, CA: Sage Publications.

Finkelhor, D., \& Dziuba-Leatherman, J. (1994). Victimization of children. American Psychologist, 49, 173-183. 
Gelles, R. J., \& Straus, M. A. (1988). Intimate violence: the causes and consequences of abuse in the American family. New York: Simon \& Schuster.

Goddard, C., \& Liddell, M. (1995). Child abuse fatalities and the media: lessons from a case study. Child Abuse Review, 4, 356-364.

Goetting, A. (1988). When parents kill their children: Detroit 1982-1986. Journal of Family Violence, 3, 339-346.

Hargrave, D. R., \& Warner, D. P. (1992). A study of child homicide over two decades. Medicine, Science, and Law, 32, 247-250.

Hewitt, B. (1997). A day in the life. People (December), 48-58.

Hicks, R. A., \& Gaughan, D. C. (1995). Understanding fatal child abuse. Child Abuse \& Neglect, 19, 855-863.

Hide, D. W., \& Guyer, B. M. (1982). Prevalence of infant colic. Archives of Diseases in Child, 57, 559-560.

Holden, C. E., Burland, A. S., \& Lemmen, C. A. (1996). Insanity and filicide: women who murder their children. New Directions for Mental Health Services, 69, 25-34.

Holmes, T. H., \& Masuda, M. (1974). Life change and illness susceptibility. In B. S. Dohrenwend \& B. P. Dohrenwend (Eds.), Stressful life events: their nature and effects (pp. 45-72). New York: Wiley.

Hontela, S., \& Reddon, J. R. (1996). Infanticide of defective newborns: an old midwife's story. Psychological Reports, 79, 1275-1278.

Hunter, R. S., \& Kilstrom, N. (1979). Breaking the cycle in abusive families. American Journal of Psychiatry, 136, 1320-1322.

Husain, A., \& Daniel, A. (1984). A comparative study of filicidal and abusive mothers. Canadian Journal of Psychiatry, 29, 596-598.

Jacquot, C., \& Roberts, D. (1988). Fatal child abuse and neglect in Oregon: 1985-1988. Salem, OR: State Department of Human Resources, Children's Services Division.

Jason, J. (1983). Child homicide spectrum. American Journal of Disease and Children, 137, 578-581.

Jason, J., \& Andereck, N. D. (1983). Fatal child abuse in Georgia: the epidemiology of severe child physical abuse. Child Abuse \& Neglect, 7, 1-9.

Jason, J., Gilliand, J. C., \& Tyler, C. W. (1983). Homicide as a cause of pediatric mortality in the United States. Pediatrics, 72, 191-197.

Kasim, M. S., Cheah, I., \& Shafie, H. M. (1995). Childhood deaths from physical abuse. Child Abuse \& Neglect, 19, 847-854.

Kaufman, J., \& Zigler, E. (1987). Do abused children become abusive parents? American Journal of Orthopsychiatry, 57, 186-192.

Kempe, C. H., Silverman, F. N., Steele, B. F., Droegemueller, W., \& Silver, H. K. (1962). The battered-child syndrome. Journal of the American Medical Association, 182, 105-112.

Korbin, J. E. (1987). Incarcerated mothers' perceptions and interpretations of their fatally maltreated children. Child Abuse \& Neglect, 11, 397-407.

Krugman, R. D. (1995). Commentary. The review of child maltreatment fatalities: snatching victory from the jaws of defeat. Child Abuse \& Neglect, 19, 843-845.

Margolin, L. (1990). When vocabularies of motive fail: the example of fatal child abuse. Qualitative Sociology, 13, 373-385.

Merrill, L. L., Hervig, L. K., \& Milner, J. S. (1996). Childhood parenting experiences, intimate partner conflict resolution, and adult risk for child physical abuse. Child Abuse \& Neglect, 20, 1049-1065.

Mitchell, L. (1989). Report on fatalities from NCPCA. Protecting Children, 6, 3-5.

Mollerstrom, W. W., Patchner, M. A., \& Milner, J. S. (1995). Child maltreatment: the United States Air Force's response. Child Abuse \& Neglect, 19, 325-334.

Mustin, H. D., Holt, V. L., \& Connell, F. A. (1994). Adequacy of well-child care and immunizations in US infants born in 1988. Journal of the American Medical Association, 272, 1111-1115.

Myers, S. A. (1970). Maternal filicide. American Journal of Disease and Children, 120, 534-536.

Pitt, S. E., \& Bale, E. M. (1995). Neonaticide, infanticide, and filicide: a review of the literature. Bulletin of the American Academy of Psychiatry and the Law, 23, 375-386. 
Plass, P. S. (1993). African American family homicide patterns in partner, parent, and child victimization, 1985-1987. Journal of Black Studies, 23, 515-538.

Raiha, N. K., \& Soma, D. J. (1997). Victims of child abuse and neglect in the US Army. Child Abuse \& Neglect, $21,759-768$.

Resnick, P. J. (1969). Child murder by parents: a psychiatric review of filicide. American Journal of Psychiatry, 126, 325-334.

Resnick, P. J. (1970). Murder of the newborn: a psychiatric review of neonaticide. American Journal of Psychiatry, 176, 1414-1420.

Rosen, L. N., \& Martin, L. (1996). The measurement of childhood trauma among male and female soldiers in the US Army. Military Medicine, 161, 342-345.

Schloesser, P., Pierpont, J., \& Poertner, J. (1992). Active surveillance of child abuse fatalities. Child Abuse \& Neglect, 16, 3-10.

Schmidt, P., Grab, H., \& Madea, B. (1996). Child homicide in Cologne (1985-94). Forensic Science International, 79, 131-144.

Schroeder, D. H., \& Costa, P. T. (1984). Influence of life event stress on physical illness: substantive effects or methodological flaws? Journal of Personality and Social Psychology, 46, 853-863.

Somander, L. K., \& Rammer, L. M. (1991). Intra- and extrafamilial child homicide in Sweden. Child Abuse \& Neglect, 15, 45-55.

Starling, S. P., Holden, J. R., \& Jenny, C. (1995). Abusive head trauma: the relationship of perpetrators to their victims. Pediatrics, 95, 259-262.

Thompson, L., \& Wilson, D. (1989). Report on child fatalities related to child abuse and neglect: April 1986-April 1988. Olympia, WA: State Department of Social and Health Services, Division of Child and Family Services.

Trocme, N., \& Lindsey, D. (1996). What can homicide rates tell us about the effectiveness of child welfare services? Child Abuse \& Neglect, 20, 171-184.

US Department of Health and Human Services. (1992). Homicide surveillance, 1979-1988. Morbidity and Mortality Weekly Report, Center for Disease Control Surveillance Summaries, (41) SS-3, p. 10.

US Department of Health and Human Services. (1996). Child maltreatment 1994: reports from the states to the national child abuse and neglect. Washington, DC: US Government Printing Office.

US Department of Health and Human Services. (1997). Child maltreatment 1995: reports from the states to the national child abuse and neglect data system. Washington, DC: US Government Printing Office.

Voss, H. L., \& Hepburn, J. R. (1968). Patterns in criminal homicide in Chicago. Journal of Criminal Law, Law Criminology, and Police Science, 59, 499-508.

Wardinsky, T. D., Vizcarrondo, F. E., \& Cruz, B. K. (1995). The mistaken diagnosis of child abuse: a three-year USAF Medical Center analysis and literature review. Military Medicine, 160, 15-20.

Wolfgang, M. E. (1958). Patterns of criminal homicide. Philadelphia: University of Pennsylvania Press.

Zumwalt, R. E., \& Hirsch, C. S. (1987). Pathology of fatal child abuse and neglect. In D. Helfer \& R. Kempe (Eds.), The battered child (pp. 247-284). Chicago, IL: University of Chicago Press.

\section{Résumé}

Objectif: cette étude décrit les facteurs relatifs à des sévices mortels chez trois groupes d'âge dans les United States Air Forces (USAF).

Méthode: Les dossiers de 32 cas d'enfants avec preuves de sévices mortels dans les USAF ont été révisés indépendamment selon 60 facteurs pré-définis.

Résultats: Les garçons étaient surreprésentés parmi lestrès jeunes enfants victimes (de 1 à 4 ans) et parmi les enfants (de 4 à 15 ans) mais non parmi les bébés (de 24 heures à un an). Les Américains d'origine africaine, bébés et agresseurs, étaient sur-représentés. Les plus jeunes des victimes étaient plus susceptibles d'avoir déjà été maltraitées physiquement par l'agresseur. Les agresseurs étaient le 
plus souvent des hommes et les pères biologiques des victimes. Les agresseurs des bébés et des jeunes enfants disaient avoir été eux-mêmes agressés dans leur enfance, alors que les agresseurs d'enfants rapportaient le maximum de consultations en hygiène mentale. Les familles des victimes ont fait état de causes de tensions significatives. Les familles des jeunes enfants victimes étaient plus souvent divorcées, séparées ou monoparentales. Les incidents avec les bébés et les jeunes enfants ont eu tendance à avoir lieu sans témoin. Les incidents avec des enfants ont eu tendance à avoir lieu en présence des frères et soeur et/ou de la mère. Les incidents mortels ont été plus fréquents durant les fins de semaine, dans la maison et favorisés par quelque perturbation familiale.

Conclusions: Les différences que l'on a trouvées trouvées entre groupes concernant les facteurs intragroupes relatifs aux infanticides de bébés et d'enfants pourraient servir à développer des efforts de prévention mieux adaptés ainsi qu'à servir de guide pour les recherches futures.

\section{Resumen}

Objetivo: El presente estudio describe los factores relacionados con el maltrato que tiene como consecuencia la muerte del niño/a en tres grupos de edades de familias pertenecientes a las Fuerzas Aéreas de Estados Unidos de América.

Método: Se revisaron los ficheros de 32 casos confirmados de maltrato infantil con consecuencia de muerte en las Fuerzas Aéreas de Estados Unidos de América en base a 60 factores predeterminados. Resultados: Los varones estuvieron sobrerepresentados en el grupo de niños/as de entre 1 y 4 años y en los niños/as de entre 4 y 15 años, pero no en los niños menores de 1 año de edad. Las víctimas y los perpetradores afroamericanos estuvieron sobrerepresentados. Las víctimas más jóvenes tenían más probabilidades de haber sido previamente maltratadas físicamente por el mismo perpetrador. Los perpetradores fueron fundamentalmente varones y los padres biológicos de las víctimas. Los maltratadores de los grupos de niños/as de menos de 1 año y de entre uno y cuatro años notificaron una historia de maltrato infantil, mientras que los maltratadores del grupo de niños/as de entre 4 y 15 años notificaron la frecuencia más elevada de contactos con salud mental. Las familias de las víctimas notificaron un número elevado y significativo de situaciones estresantes. Las familias de las víctimas de entre 1 y 4 años eran con más frecuencia divorciadas, separadas o solteras. Los incidentes con niños/as de menos de 1 año y de entre 1 y 4 años tienden a ocurrir sin testigos. En el grupo de niños/as mayores los incidentes tienden a ocurrir con la presencia de los hermanos y/o de la madre. Los incidentes fatales fueron más frecuentes en el fin de semana, en casa e iniciados tras un conflicto familiar.

Conclusiones: Las diferencias entre los grupos en factores relacionados con el homicidio de los niños/as pueden servir de ayuda en el desarrollo de esfuerzos de prevención del maltrato y pueden servir como guías. 